\title{
Challenges That Make/Break the Athlete's Quest to Become an Entrepreneur: A Qualitative Study About Fans' Perceptions
}

Authors' contribution:

A) conception and design of the study

B) acquisition of data

C) analysis and interpretation of data

D) manuscript preparation

E) obtaining funding
Syed Ali Hasaan ${ }^{1 \mathrm{~A}-\mathrm{E}}$, Shahid Nawaz ${ }^{1 \mathrm{C}, \mathrm{D}}$, Syed Javed Iqbal ${ }^{\text {IC,E }}$, Jawaria Khalid ${ }^{2 \mathrm{~A}, \mathrm{~B}}$

${ }^{1}$ Islamia University Bahawalpur, Pakistan

${ }^{2}$ Zainab Degree Collage, Multan

ABSTRACT

Athletes are a new type of celebrity in the world. Following other celebrities, there are several examples of athletes who have used their persona of fame to go a step further with their so-called personal brands and actually launch products carrying their names. As athletes are considered brands in themselves, these sorts of activities (i.e., introducing a product brand) are considered as an extension of the athlete's brand. Given the nature of the research, this study employed a qualitative design. A purposeful convenience sampling technique was employed to select study participants according to a set of predetermined criteria. The final sample comprised nine fans. The fans identified five major factors that could be important in the context of an athlete's decision to start his/her own brand. The five identified factors that could decide the fate of an athlete's brand extensions were the athlete's origin, extension fit, gender, performance, and impression. According to fans, these factors play an important role in the athlete's venture as an entrepreneur. The study suggests that although fans understand that athletes are brands in themselves, Pakistani fans are not fond of the idea of athletes becoming entrepreneurs due to the fans' emotional attachment to the athletes. As this is the first study expressing fans' perspectives in the context of athlete brand extension, this study is an addition to the academic literature and theories of athlete branding and athletes as entrepreneurs.

Athletes are a new type of celebrity in the world. They amuse millions of people with their on-field performance and off-field activities (Yu 2005). Not only are they seen as entertainers, they have also achieved the status of national heroes and role models. Compared to past perceptions of heroes, they have changed the standard of what it is to be a hero. Presently, athletes are more popular than war heroes and legendary characters (Archetti 2001). As a result, they are the most prominent celebrities of modern times. As sports have become an integral part of modern societies (White \& Absher 2013), athletes have become more prominent figures. They have surpassed the image of the sportsperson and become a symbol of society and country.

Arai, Ko, and Kaplanidou (2013) mentioned that every athlete is a brand, as every athlete owns a unique name, appearance, and other individual characteristics (i.e., personality and image) (Williams et al. 2015). Hasaan et al. (2016) positively identified the dimensions of athlete brands and also studied the 
implication of the athlete brand among fans (Hasaan 2016). Consequently, as with any other brand, athletes are also required to perform actions to boost the image that is built upon their on-field and off-field accomplishments (Cortsen 2013). There are several examples of athletes who have used their persona of fame to go a step further with their so-called personal brands and actually launch products carrying their names (Stallen et al. 2010). Kumar (2003) mentioned that when one shifts a brand into a new category, he/she has to attract the customer to buy that brand. In the case of celebrities (i.e., athletes), they benefit from their influence, and positive emotions that have successfully shifted from the personality to the product cast a positive impression of the endorsed product (Hunter 2009; Stallen et al. 2010).

The athlete-turned-entrepreneur (also known as an athlete with his or her own brand) is a new trend in the world of sports. Previously, athletes acted as endorsers only; now, they are introducing their own brand by themselves or collaborating with big brands. As athletes are considered brands in themselves, these sorts of activities (i.e., introducing a product brand) are considered an extension of the athlete's brand. There are numerous examples of brand extensions in sports, ranging from new leagues and tournaments to broadcasting stations and pay-per-view programs (Apostolopoulou 2002). Specific to athletes, there are several examples of athletes who took a step further and launched sporting or non-sporting products carrying their names instead of just being an endorser. For example, Björn Borg, the famous tennis player, iscurrently well known for his bags and underwear (Papp-Váry 2011). In contrast, Annika Sorenstam, a former Swedish golfer, introduced the "Annika" brand based on golf-related products (Cortsen 2013). Mujkic, Staškevičiūtè-Butiene, and Valantine (2016) noted that the introduction of the athlete's own branded products often has a positive impact on his/her image as the extension products may contribute to increased emotional attachment and help delay the decline of an athlete's brand. Ratten (2015) described how athletes-turned-entrepreneurs actually utilize human capital in the form of the social, emotional, and leadership abilities of athletes.

Although previous studies have confirmed that athlete entrepreneurship is a positive activity for an athlete and his or her brand, the situation is not same everywhere. Recently in the Indian subcontinent, many athletes have been criticized by their fans for their commercial and social media activities; this criticism is neither new nor unique. For instance, M S Dhoni's house was attacked after an Indian loss as violent fans claimed that Dhoni was banking more on modeling than wicket keeping and batting. In another story, a lot of people blamed Anushka Sharma (an Indian film actress and girlfriend of Indian cricketer Virat Kohli) for India's defeat by Australia in the Cricket World Cup. Also, Ahmad Shehzad was criticized for putting up a selfie-show with Shahid Afridi before the 2015 World Cup, where the Pakistan team started off their campaign on a very bad note with two losses in their first two matches. This argument even hit the athlete's own brands, as some argued that for 29 years Afridi was just acting as an entertainer and should have come during match intervals to entertain the crowd and sell his kurtas (i.e., Shahid Afridi introduced his clothing brand in Pakistan).

The above-mentioned examples clearly form opposite conclusions to what we have found in the literature. When a team lost a match, the so-called die-hard fans started to break their television sets, hate their heroes, and throw stones at their houses as punishment for the loss. As this situation could be very critical in the context of an athlete's efforts to establish a name brand, Stegemann (2006) mentioned that customer attitude is an important factor when considering unique brand extensions. However, to our best knowledge, no study has discussed South Asian fans or focused on the fans' perspectives about athletes becoming entrepreneurs. Therefore, the purpose of this study was to develop an understanding with fans regarding how they perceive athletes as endorsers and entrepreneurs. Following this line of reasoning, this study represents an attempt to fill a gap in the literature by discussing fans' perspectives about their favorite athletes' commercial activities and their reactions to their favorite athletes' best and worst sports performances. This study aims to provide a perspective on athlete entrepreneurship that has not yet been discussed.

\section{The method}

Given the nature of the research, this study employed an inductive qualitative design. The author assumed that this method would be the most appropriate in eliciting meaning and gaining in-depth knowledge 
regarding athlete entrepreneurship that is currently absent from the literature. To address the shortage of indepth examinations in this area, this approach is intended to be a starting point for future investigations.

A purposeful convenience sampling technique was employed to select study participants according to a set of predetermined criteria (Patton 2002). The convenience sampling strategy is advantageous in situations wherein researchers want to collect data that can beused as a springboard for future studies (Berg \& Lune 2011). The purpose of using the criteria was to select a genuine "athlete fan" who is well aware of his/her onfield and off-field activities. Following Crawford's (2004) definition, a person who considers himself/herself obsessed with sports (i.e., team, athlete, celebrity) is a fan. This study set the participant criteria as:

1. Must consider themselves a sports fan,

2. Must have at least one local and one international favorite athlete,

3. Has watched games (live or on television) of their favorite athletes during the current season, and

4. Has followed these particular athletes for at least one year on social and mass media.

All interviews were conducted in settings preferred by the interviewees. The final sample comprised nine fans. The participants, composed of both males and females, came from a diverse range of professions (see Table 1).

Table 1. Participants

\begin{tabular}{lllll}
\hline No. & Name & Profession & Favorite Local Athlete & Favorite International Athlete \\
\hline 1 & Ahmad & Lawyer & Sarfraz Ahmad (Cricket) & Cristiano Ronaldo (Football) \\
2 & Kaleem & Doctor & Aisam-ul-Haq (Tennis) & Roger Federer (Tennis) \\
3 & Arslan & Teacher & Hassan Ali (Cricket) & Chris Gyle (Cricket) \\
4 & Faiza & Student & Shahid Afridi (Cricket) & Darren Sammy (Cricket) \\
5 & Faheem & Bank Manager & Shoaib Malik (Cricket) & Lionel Messi (Football) \\
6 & Kashan & Teacher & Shahid Afridi (Cricket) & Cristiano Ronaldo (Football) \\
7 & Azfar & Student & Saeed Ajmal (Cricket) & Paul Pogba (Football) \\
8 & Usman & Sports Journalist & Muhammad Waseem (Boxing) & Floyd Mayweather (Boxing) \\
9 & Sana & Teacher & Shahid Afridi (Cricket) & Steven Smith (Cricket) \\
\hline
\end{tabular}

Source: Own Study.

Interviews were conducted to obtain a deeper understanding of fans' thoughts regarding their favorite athletes becoming entrepreneurs. A qualitative technique was employed to suggest possible reactions of the fans towards their favorite athlete's commercial activities. All interviews were conducted for two months. These interviews were audio-recorded and transcribed verbatim. Prior to the interviews, all participants were asked to sign a voluntary participation form that explained the purpose of the study. A semi-structured interview guide was developed, which covered the key issues mentioned earlier. For example, the questions aimed at understanding the following:

1. Does your favorite player own any brand? Do you recognize any commercial or brand which was endorsed by your favorite player?

2. Are you ever influenced by your favorite athlete when buying anything? What about others?

3. What do you think people and fans think about players who endorse a brand?

As is the case with numerous qualitative methods, the researcher served as the instrument to elicit the data. To do so, questions were asked to gather more details (Kvale 1996). For instance, real-life examples were often used in follow-up questions to clarify participants' replies to questions. However, the interview guide remained the same in its structure and sequence of questions for every interview.

The analysis commenced after conducting the first interview in the current study. This strategy allows the researchers to become more familiar with the participants' responses (Marshall \& Rossman 1995). Two levels of coding were adopted for the current study: the open coding level and the axial level. Open coding was employed for the initial analysis. Open coding is defined as separating data and defining concepts to stand for blocks of raw data (Corbin \& Strauss 2008). To do this, the interview responses were read until a good grasp of the data was obtained. The researcher referred to the study purpose and interview guide in the process 
of coming up with initial themes. Once the initial themes were identified, the researcher classified them into more defined, concrete themes; in some cases, they combined similar themes. This process is known as "axial coding," which is defined as the process of cross-matching the initial themes to one another (Corbin \& Strauss 2008). Results in this study were elaborated from the themes arising from the axial coding process.

\section{Findings}

The results of the study are discussed according to the responses of the fans. The fans identified five major factors that could be important in the context of an athlete's decision to start his/her own brand. The five identified factors that could decide the fate of an athlete's brand extensions are the athlete's origin, extension fit, gender, performance, and impression. These factors play an important role according to fans when talking about the athlete as an entrepreneur.

\section{Theme 1. Origin: Local vs. international}

Participants of the study agreed that the origin of the athlete is an important factor when considering the idea of the athlete as a brand. However, surprisingly, the participants of the study mentioned that local athletes do not possess the star power that international athletes do. According to fans, local athletes have more duties to obey the norms, while international athletes are usually given more space. For instance, one of our participants mentioned that:

International athletes/stars own the whole world. They are the world's common pride. But at the national level, athletes are a country's ambassadors. Their image is the country's image; their performance is the country's performance. That is why people flair up more when it comes to local heroes, and at the end a fan's frustration is focused on the athlete's representatives, such as the athlete's social media account, the athlete's brand, etc. [Arslan].

In this regard, we can understand that international athletes have leverage to extend their brand more easily. However, local athletes have more of a challenge as they have to face a more hybrid situation (i.e., their own off- and on-field activities affect their brand). On the one hand, local athletes have to perform continuously well, but on the other, one memorable performance can help them achieve the status that takes a long time forthe international athlete to achieve. For example, one of our participants mentioned that:

Fakhar Zaman's performance in Champions Trophy 2017 is the best example of how when you represent your country and represent it well, one century against India (the typical opponent of Pakistan) makes you the biggest brand in the country. While in tennis, losing doesn't matter a whole lot, nor will a single win make you a top brand [Saad].

\section{Theme 2. Extension Fit: Sporting vs. non-sporting product extension}

Our participants claimed that the nature of the product brand is also important when an athlete decides to enter the corporate world. For instance:

When an athlete tries to sell sports-related products, it causes more attention than nonsporting products. For example, if Roger Federer makes a brand that sells tennis-related products, it attracts lots of people because it will be like professional advice. On the other hand, if he decides to make a hotel chain or fast food chain, of course he will attract his fans, but it will not attract other people [Faheem].

In this context, we can assume that athletes have to decide carefully what products they are going to launch. However, we have seen many athletes introducing their brand with sporting and non-sporting goods with mixed examples. 
Theme 3. Gender: Male vs. female athletes

Gender also plays an important role when deciding the fate of an athlete's brand extension. Our participants positively identified that the gender of an athlete is a significant factor for that athlete's brand extension. Usually, female athletes receive more attention when launching their products. Five out of nine participants acknowledged that female athletes have superiority compared to male athletes when it comes to athlete off-field media coverage. One of our participants mentioned that:

Although Pakistan is a male-dominant society, females in the field of sports attain more consideration from their fans due to their glamour, appearance, and personality. They get more media coverage, so their on-and off-field activitiesare highlighted by the media due to the glamour factor. That is why female athletes often get more attention than male athletes [Azfar].

\section{Theme 4. Performance: On-field activities}

It is almost impossible to become a top brand without performing consistently well. Athletes are a product of their performances, so when they do not perform well it affects their image, name, and brand.

What does an athlete sell? Basically his/her performance. So when his performance is not good, how will people trust him? It is like a politician with corruption charges defending others. So when your base is not solid, you will not survive; in the case of an athlete's base, it is the athlete's performance on the field [Faiza].

According to this comment, it is very clear that the athlete's brand is based on his/her athletic performance, athletic success, and athletic achievements. All of our participants agreed that the performance of an athlete is directly proportional to the athlete's brand, especially for local athletes.

\section{Theme 5. Impression: Athlete's impression}

Impression counts a lot. A positive impression causes a positive effect, while a negative impression casts a negative effect apart from what the athlete really is. Six of our participants acknowledged the importance of impression management in the context of an athlete's brand extension. For instance, one of our participants, Sana, mentioned that:

It is like Lance Armstrong selling cycles now. But when he was the hero of many (before the doping scandal), he could sell anything to you because he was a sports hero. Another example is Wasim Akram. When he was convicted for match-fixing, many started to dislike him. But after many years, he has rebuilt his image and he is in every second commercial selling washing powder to air conditioners.

\section{Discussion}

The current study focused on examining fans' perspectives regarding the trend of athletes creating their own brands. The main goal of the study was to capture fans' opinions so as to gain a deeper understanding of athletes-as-entrepreneurs in the context of athletes' brands. The study contributes to the literature by (1) discussing the concept of athletes' brand extensions (athletes' own branding) and (2) presenting and portraying the fans' point of view. As fans are customers in the context of athlete branding, this study presents the customer's view about the brand, a viewpoint that is missing in the literature on athlete brands. The study found the five major factors that play important roles when athletes decide to introduce their own brands. According to the fans, the origin of the athlete, gender of the athlete, sport the athlete plays, and the athlete's sporting performance are the main factors contributing to the extension of an athlete's brand (see Figure 1). 
Figure 1. Result presentation

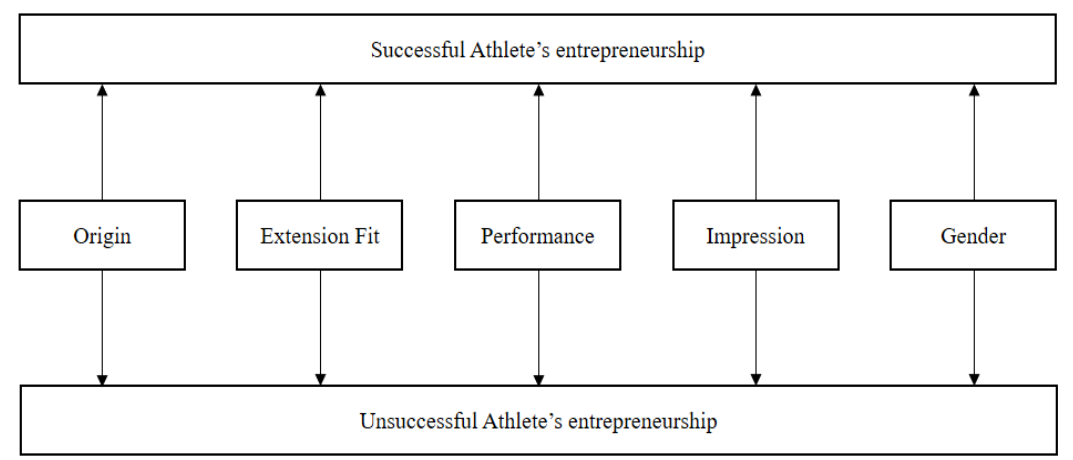

Source: Own Study.

The unique response the fans expressed is that local athletes face a tough time becoming entrepreneurs. Past studies have positively identified that the location/origin of the athlete could be a boost for athletes in their pursuit of a brand. As Fletcher (2011) mentioned, an athlete's ethnicity is an important aspect for generating support among fans. Shakib and Veliz (2012) mentioned that the origin of an athlete might be helpful for athlete branding. Kunkel, Hill, and Funk (2013) identified that interest in a specific sport is often a reason to follow an athlete. Nevertheless, the popular sport in the Indian subcontinent is cricket. Cricket has always been renowned for its international-level competitions, unlike most other European sports (i.e., football, basketball) where clubs and domestic leagues are more prominent. This type of competition has often caused the result of a cricket match to be cited as a battle for national sovereignty and independence (Malcolm 2001), as it is played between two countries. This could be one of the reasons that our fans mentioned that when an athlete plays against a rival country (i.e., Pakistan vs. India or England vs. Australia), fans conceive it as war, and losers of war are never forgotten. In contrast, athletes of other sports (i.e., tennis, football) or other countries that represent league teams (i.e., Ronaldo of football) do not face this tough situation and their winning or losing are not perceived as a matter of their country's pride. In this sense, surprisingly, in most popular sports local origin is a kind of constraint in extending the athlete's brand unless the athlete's performance is phenomenal. That is why athlete branding has been more successful among the athletes of highly commercialized fields of sport (i.e., tennis, football, basketball, baseball). Cricketers are not beneficiaries in this case, and it is rare for a cricketer to become an international star, although they enjoy the status of national heroes in their home countries (Hasaan 2016).

The participants of the study mentioned that an athlete's performance is a major contributing factor when extending his brand. Previous studies have already emphasized the importance of an athlete's top performance for their brand survival. An athlete is the product of his or her image, and that image is built mainly on his/her on-field performance. Cortsen (2013) mentioned that an athlete's brand is a hybrid type of brand that receives a response according to the athlete's image (i.e., when something positive or negative happens it causes the same effect on the athlete's brand). The participants of the study mentioned the same phenomenon; however, in this study the hybrid nature of the brand mainly depends upon the athlete's performance. Hasaan et al. (2016) mentioned that the athlete's brand is built around the athlete's on-field performance. Furthermore, the study categorizes the athlete's on-field activities by behavior, team, achievements, style of play, and skills. Thus, this study is in line with the previous studies that have highlighted that athlete brand and athlete image is based on the athlete's field performance.

Participants of this study also identified the gender of the athlete as a catalyst factor enhancing the brand's range. This is somehow in line with the previous literature, as Pope (2010) mentioned that a fan's preference for an athlete can be derived from the athlete's appearance. Also, an athlete's appearance or physical attractiveness tends to be important for both male and female fans (van Amsterdam et al. 2012). However, these are not gender specific, as our participants preferred females over males. In this line of reasoning, Lieb 
(2013) acknowledged that female pop stars have an edge over male singers. Therefore, the results of this study replicate this concept in sports branding as well. Also, in the Chinese context, female athletes are a preferred choice for endorsements compared to male athletes as their attractiveness works in favor of the campaigns (Liu \& Brock 2011).

Impression management is an important aspect in the context of athlete branding. It also matters during brand extension. As Rojek (2001) mentioned, impression management is one of the major contributing factors in the creation of modern-day celebrities. That is, an athlete's efforts to create, maintain, or change his/her image is vital in enhancing fans' perceptions of them. Also, impression management is akin to brand management strategy (Agyemang \& Williams 2013). The participants of this study also positively identified that the overall impression of an athlete plays a vital role when extending an athlete's brand.

The nature of the product is also an important factor to consider when discussing brand extension. Our participants' response is in accordance with past studies. Albrecht et al. (2013) identified that there is a need for a good fit between the parent brand and the extension, that is, the nature of the product introduced by an athlete is important in the context of a successful brand extension. Participants of this study have mentioned that if an athlete introduces sports-related products or products related to his/her personality, there are more chances of success compared to a non-sporting product. In summary, the current study discussed the possibility of athlete brand extension among Pakistani fans and found five major factors (athlete's origin, performance, gender, impression, and product fit) that can both positively and negatively affect the efforts of athletes to extend brand equity.

\section{Conclusion}

The current study is a qualitative inquiry about the perceptions of fans regarding athlete brand extension. The study suggests that although fans understand that athletes are brands in themselves, due to their emotional attachment Pakistani fans are not fond of the idea of athletes becoming entrepreneurs. The fans identified five factors that can determine the successful or unsuccessful extension of an athlete's brand: the athlete's origin, performance, gender, impression, and product fit. As this is the first study that has expressed the fans' perspective in the context of athlete brand extension, this study is an addition to the academic literature and theories of athlete branding and athletesas entrepreneurs. Furthermore, this study was composed of Pakistani fans, and thus the study demonstrates a unique range of potential applications among fans that belong to the South Asian subcontinent or Muslim societies.

This study also offers guidance to athletes' marketing teams and managers to extend athletes' brands and their equity. As athletes are global entities and international brands, there is a need to extend their brands in various countries and cultures. This study has addressed the viewpoint of fans living in Pakistan, which can prove to be a massive increase in an athlete's brand equity. Keeping in mind the five major factors discussed by the participants of the study, an athlete's marketing team could develop a strategy to face these challenges and take advantage of the market situation.

Also, as with any study, there are limitations that should be acknowledged and considered for future research. As this study is qualitative in nature, there is a need to collect quantitative data and examine the proposed attributes. Therefore, even though qualitative data provides an in-depth understanding of this topic, future studies could employ quantitative methods in order to provide further support for these findings with a larger sample of sports fans.

\section{REFERENCES}

Agyemang, K.J.A. \& Williams, A.S. (2013). Creating Revenue via Organisational "Brandpression" Management (OBpM): A Marriage of Brand Management and Impression Management in Professional Sport. International Journal of Revenue Management 7(2), 171-81.

Albrecht, C-M., Backhaus, C., Gurzki, H., \& Woisetschläger, D. (2013). Drivers of Brand Extension Success: WhatReally Matters for Luxury Brands. Psychology \& Marketing 30(8), 647-659.

van Amsterdam, N., Knoppers, A., Claringbould, I., \& Jongmans, M. (2012). A Picture Is Worth a Thousand Words. Constructing (Non-) Athletic Bodies. Journal of Youth Studies 15(3), 293-309. 
Apostolopoulou, A. (2002). Brand Extensions by U.S. Professional Sport Teams: Motivations and Keys to Success. Sports Marketing Quarterly 11(4), 205-14.

Arai, A., Ko, Y., \& Kaplanidou, K. (2013). Athlete Brand Image: Scale Development and Model Test. European Sport Management Quarterly 13(4), 383-403.

Archetti, E.P. (2001). The Spectacle of a Heroic Life: The Case of Diego Maradona. In D.L. Andrews \& S.J. Jackson (Eds.), Sport Stars: The Cultural Politics of Sporting Celebrity (pp. 151-63). New York, NY: Routledge.

Berg, B.L. \& Lune, H. (2011). Qualitative Research Methods for the Social Sciences ( $8^{\text {th }}$ ed.). Boston, MA: Allyn and Bacon.

Corbin, J. \& Strauss, A. (2008). Basics of Qualitative Research: Techniques and Procedures for Developing Grounded Theory ( $3^{\text {rd }}$ ed.). London, UK: Sage.

Cortsen, K. (2013). Annika Sörenstam - A Hybrid Personal Sports Brand. Sport, Business and Management: An International Journal 3(1), 37-62.

Crawford, G. (2004). Consuming Sport: Fans, Sport and Culture. New York, NY: Routledge.

Fletcher, T. (2011). "Who Do 'They' Cheer For?”: Cricket, Diaspora, Hybridity and Divided Loyalties Amongst British Asians. International Review for the Sociology of Sport 47(5), 612-31.

Hasaan, A. (2016). Establishing Athlete Brand in Cricket: Fan's Perception about Foreign Cricketers in Pakistan Super League (PSL). Pamukkale Journal of Sport Sciences 7(3), 23-39.

Hasaan, A., Kerem, K., Biscaia, R., \& Agyemang, K.J.A. (2016). Athlete Brand Construction: A Perspective Based On Fans' Perceptions. Motriz: Revista de Educação Física 22(3), 144-59.

Hunter, E. (2009). Celebrity Entrepreneurship and Celebrity Endorsement: Similarities, Differences and the Effect of Deeper Engagement. Unpublished doctoral dissertation, Jönköping International Business School, Jönköping, Sweden.

Kumar, N. (2003). Kill a Brand, Keep a Customer. Harvard Business Review 81(12), 86-95.

Kunkel, T., Hill, B., \& Funk, D.C. (2013). Brand Architecture, Drivers of Consumer Involvement, and Brand Loyalty With Professional Sport Leagues and Teams. Journal of Sport Management 27(3), 177-92.

Kvale, S. (1996). InterViews: An Introduction to Qualitative Research Interviewing. Thousand Oaks, CA: Sage.

Lieb, K. (2013). Gender Branding and the Modern Music Industry: The Social Construction of Female Popular Music Stars. New York, NY: Routledge.

Liu, M.T. \& Brock, J.L. (2011). Selecting a Female Athlete Endorser in China: The Effect of Attractiveness, Match-Up, and Consumer Gender Difference. European Journal of Marketing 45(7/8), 1214-35.

Malcolm, D. (2001). "It's Not Cricket”: Colonial Legacies and Contemporary Inequalities. The Journal of Historical Sociology 14(3), 253-75.

Marshall, C. \& Rossman, G.B. (1995). Designing Qualitative Research (2 ${ }^{\text {nd }}$ ed.). Thousand Oaks, CA: Sage.

Mujkic, D., Staškevičiūtè-Butienè, I., \& Valantinè, I. (2016). Elite Athletes’ Motivation to Create Personal Brand. In The 9th Conference of the Baltic Sport Science Society, April 27-29, 2016 (p. 67-68). Kaunas, Lithuania.

Papp-Váry, Á. (2011). The Use of Sports Celebrities in Advertising: Best and Worst Practices. In Proceedings - 9th International Conference on Mangement, Enterprise and Benchmarking, November 17-18, 2011 (pp. 259-270).

Budapest, Hungary.

Patton, M.Q. (2002). Qualitative Research and Evaluation Methods. Newbury Park, CA: Sage.

Pope, S. (2010). "Like Pulling Down Durham Cathedral and Building a Brothel": Women as "New Consumer" Fans? International Review for the Sociology of Sport 46(4), 471-87. http://irs.sagepub.com/cgi/doi/10.1177/1012690210384652.

Ratten, V. (2015). Athletes as Entrepreneurs: The Role of Social Capital and Leadership Ability. International Journal of Entrepreneurship and Small Business 25(August), 442-55.

http://www.inderscienceonline.com/doi/abs/10.1504/IJESB.2015.070217.

Rojek, C. (2001). Celebrity. London, UK: Reaktion Books.

Shakib, S. \& Veliz, P. (2012). Race, Sport and Social Support: A Comparison Between African American and White Youths' Perceptions of Social Support for Sport Participation. International Review for the Sociology of Sport 48(3), 295-317.

Stallen, M., Smidts, A., Rijpkema, M., Smit, G., Klucharev, V., \& Fernández, G. (2010). Celebrities and Shoes on the Female Brain: The Neural Correlates of Product Evaluation in the Context of Fame. Journal of Economic Psychology 31(5), 802-811.

Stegemann, N. (2006). Unique Brand Extension: Challenges for Luxury Brands. Journal of Business and Economics Research 4(10), 57-68. 
White, W.D. \& Absher, K. (2013). Red Devils, Royals, and the River Thames. Sport, Business and Management: An International Journal 3(4), 312-26.

Williams, A.S., Kim, D., Agyemang, K., \& Martin, T.G. (2015). All Brands Are Not Created Equal: Understanding the Role of Athletes in Sport-Brand Architecture. Journal of Multidisciplinary Research 7(3), 75-86.

Yu, C.C. (2005). Athlete Endorsement in the International Sports Industry: A Case Study of David Beckham. International Journal of Sports Marketing \& Sponsorship 6(3), 189-200.

AUTHOR'S ADDRESS: $\quad$ Ali Hasaan

Department of Management Sciences

Baghdad-ul-Jadid Campus

Islamia University

Bahawalpur, Pakistan

E-mail: aili_hasaan@hotmail.com

Received: 22 February 2018; Accepted: 10 April 2018 